\title{
Knowledge, attitudes and current practices of intern medical officers in Colombo District regarding legal importance of medical records
}

\author{
RS Kodithuwakku ${ }^{1}$, PBDAL Nanayakkara ${ }^{1}$, IS Pallemulla ${ }^{1}$, Tharushi AB Ranasinghe ${ }^{1 *}$, PTK Ranasinghe ${ }^{1}$, Shamini \\ Prathapan $^{2}$, Sanjaya R Hulathduwa ${ }^{3}$ \\ ${ }^{1}$ Faculty of Medical Sciences, University of Sri Jayewardenepura, Sri Lanka, \\ ${ }^{2}$ Department of Community Medicine, Faculty of Medical Sciences, University of Sri Jayewardenepura, Sri Lanka, \\ ${ }^{3}$ Department of Forensic medicine, Faculty of Medical Sciences, University of Sri Jayewardenepura, Sri Lanka.
}

\begin{abstract}
Background: The importance of knowledge, attitude and practice of medical personnel in medico-legal aspect of healthcare has been raised with the development of health care system in Sri Lanka.

Objective: To determine knowledge, attitude and current practices among interns in maintaining legally important medical records at selected hospitals of Colombo district.
\end{abstract}

Methods: A descriptive cross-sectional study was conducted among IMOs of two teaching hospitals (TH1 and TH2) and a Base hospital (BH) in Colombo district, Sri Lanka. A self-administered questionnaire was used to assess the knowledge, attitude and current practice and marks were given and categorized as either poor (less than 50\%) or good (more than and equal to 50\%). The Study was carried out among all the 81 IMOs of the selected hospitals.

Results: The BH had the highest percentage (69\%) of IMOs with good knowledge whereas TH1 had $42 \%$ and TH 2 had $47 \%$. However, there were no statistically significant differences seen among the three hospitals $(\mathrm{p}=0.238)$. Majority (82\%) of all the IMOs had good attitudes and best attitudes were seen among the IMOs of TH2 (94\%). Out of all the IMOs, $64 \%$ had good practice. Mean values related to knowledge were compared and the graduates from the 4 thUniversity had the highest percentage in terms of knowledge (85\%), attitude $(82 \%)$, current practice (15\%) and overall performance $(47 \%)$ as well.

Conclusions: There is good knowledge regarding legally important medical documents among IMOs with a good overall performance regarding legally important medical documents.

Keywords: Intern medical officers, legal importance, medical records

Received: 12 June 2019, Revised version accepted: 25 June 2019, Published: 30 June 2018. *Corresponding author: Ranasinghe TAB, $\triangle$ Email: tharushiranasinghe3@gmail.com, (D) https://orcid.org/0000-0001-8458-6122

Cite this article as: Kodithuwakku RS, Nanayakkara PBDAL, Pallemulla IS, Ranasinghe TAB, Ranasinghe PTK, Prathapan S, et al. Knowledge, attitudes and current practices of intern medical officers in Colombo District regarding legal importance of medical records. Medico-Legal Journal of Sri Lanka, 2019;7(1): 1-7 DOI: http://doi.org/10.4038/mljsl.v7i1.7387

Copyright: @ 2019 with the Medico-legal Journal of Sri Lanka.

This is an open-access article distributed under the terms of the Creative Commons Attribution 4.0 International License, which permits unrestricted use, distribution and reproduction in any medium provided the original author and source are credited.

\section{Introduction}

Sri Lanka is a country which provides free health care from womb to tomb to any citizen regardless of religion, caste or social status. As a developing country our health care setup is still considerably more doctor-centered rather than patient-centered. Therefore, information available to patients in the local setup regarding his/her treatment may be limited. Medical negligence is a topic that's increasingly receiving more attention. Due to our culture and legal system, cases of medical negligence is rarely reported. Although they are reported rarely, it may not mean that the cases of medical negligence in Sri Lanka are rare. In reality it is believed to be an iceberg phenomenon. With easy access to internet and social networking, the world is getting smaller and information gaps are being filled, and the same applies to Sri Lanka. 
The Sri Lankan patient is becoming more educated and self-aware of their rights. Therefore, our health care setup is gradually changing from being doctor centered towards being patient centered. Availability of healthcare services from the private sector aids this transition. Therefore, cases of medical negligence being reported are on the rise. ${ }^{[1]} \mathrm{With}$ these trends the topics such as "legal aspect of providing health care" and "malpractice insurance" are being discussed more than ever. And with these changes in the social climate, the importance of medical records not only as tools in providing continued and comprehensive care for the patient but also as evidence in a court of law is becoming more evident.

Medical records play a huge role when considering legal aspects of health care and by understanding the level of knowledge, attitude and current practice it would be helpful to educate the future doctors and also to renew the knowledge of all practicing doctors in an optimum way about the legal importance of medical records. The subject of medical issues and medical negligence as discussed in the journal article by Joseph Thomas states the importance of proper documentation of medical records. ${ }^{[1]}$ In addition the journal article highlights confidentiality that needs to be maintained with regards to the medical records and examples of court cases that require summoning of medical records. ${ }^{[1]}$ The facts and myths surrounding litigation against medical practitioners published in the Galle medical journal clearly explores the current medical litigation system in Sri Lanka and reveals the rising trend in the cases of medical negligence in the country. ${ }^{[2]}$ The seriousness of this issue was also highlighted in the critical review by P. Rupasinghe which elaborates on the present laws relating to medical negligence in the country and the various landmarks of medical negligence in Sri Lanka such as the Arseculeratne vs. Priyani Soysa case and Chandrika Wickramasinghe case.$^{[3]}$ Literature such as the case report by C.D.A Goonasekera brings to note the medical litigation risks the Sri Lankan doctors are exposed to and concludes that medical indemnity needs to be provided by the government for medical officers especially to the ones working in high risk setups which are both overcrowded and substandard. ${ }^{[4]}$ Well maintained medical records ensure more structured and smooth care for the patient protecting their autonomy and also would make the doctor a better expert witness in court when necessary. In addition, it would also help to avoid mishaps that would endanger a doctor in allegation of negligence.

Thus, the importance of having good knowledge, attitude and practice with regards to medical record keeping and the sheer weight it bears in safeguarding oneself from unjust claims and legal ramifications is clearly evident.

Our research was therefore conducted with the main aim of determining knowledge, attitude and current practices among the intern medical officers (IMO) of two teaching hospitals and Base Hospital in maintaining legally important medical records.

\section{Methods}

This was a cross sectional study conducted in selected hospitals in Colombo District of which two were teaching hospitals and one was a Base Hospital. All IMOs who were stationed in the selected study area were included in the study. IMO was operationalized as a physician in training who has completed medical school and has a medical degree, but does not yet have a full license to practice medicine unsupervised. All the IMOs $(\mathrm{n}=81)$ who were completing their internship in 2016 were eligible to take part in the study. Sampling was not applicable as the study was carried out among the entire selected population. A selfadministered questionnaire was distributed among the IMOs and it contains six parts. This study instrument was prepared after a through literature search which was further judgementally validated by experts in the field. A pilot study was carried out among ten medical students attached to the final year of a state University to check the accuracy of the questionnaire, to assess the clarity of questions, to change the order of the questions from a hospital that was not included in the study. Appropriate changes were made to the questionnaire. The results from the pilot study have not been taken into account in final data analysis. The anonymity of the participants and the hospitals that they belong to were protected as was proposed in the project proposal. The data that has been collected using the self-administered questionnaire were analysed using data analysing software (SPSS). Total scores for each component converted into a score out of 100 and "Good" and "poor" was divided by the mean of the distribution. Percentages of number of good and bad scores of each hospital were calculated. Significance was found using chi-square analysis and significance was set at 0.05 . Furthermore $\mathrm{z}$-scores were also calculated to see the how each total score with regard to the University of Graduation deviates from the mean of the overall distribution.

\section{Results}

Data was collected from 81 IMOs. Out of these 81 IMOs, 14 IMO were excluded from the analysis as they had not completed the question about the university of graduation. The percentage excluded amounts to $17 \%$. 
The knowledge regarding the legal importance of medical records among IMOs was assessed based on the hospital they were working and their university of graduation. Total knowledge was divided into good and poor by the mean of the distribution and the number of participants (n) who had good and bad knowledge regarding legal importance of medical records were tabled against the hospitals. Mean values of scores for each university of graduation also tabled (Table 1).

Table 1. Knowledge regarding legal importance of medical records

\begin{tabular}{|c|c|c|c|}
\hline Hospital & $\begin{array}{r}\text { Good } \\
\text { Knowledge } \\
\text { n (\%) } \\
\end{array}$ & $\begin{array}{r}\text { Bad } \\
\text { Knowledge } \\
\text { n (\%) } \\
\end{array}$ & $\begin{array}{l}\text { Total } \\
\mathbf{N}=\mathbf{8 1}\end{array}$ \\
\hline TH1 & $21(26)$ & $28(34)$ & $49(60)$ \\
\hline TH2 & 09 (11) & $10(12)$ & $19(23)$ \\
\hline $\mathrm{BH}$ & 09 (11) & $04(05)$ & $13(16)$ \\
\hline \multicolumn{4}{|c|}{ Significance-: $\chi^{2}=2.869, \mathrm{DF}=2, \mathrm{P}=0.238$} \\
\hline $\begin{array}{l}\text { University of } \\
\text { Graduation } \\
(\mathrm{N}=67)\end{array}$ & $\begin{array}{r}\text { Mean scores } \\
\text { of each } \\
\text { university } \\
\end{array}$ & $\begin{array}{r}\text { Std. } \\
\text { Deviation }\end{array}$ & Z-score \\
\hline $\mathrm{U} 1(\mathrm{~N}=24)$ & 83.33 & 9.191 & +0.1678 \\
\hline $\mathrm{U} 2(\mathrm{~N}=33)$ & 82.40 & 9.123 & +0.0638 \\
\hline $\mathrm{U} 3(\mathrm{~N}=2)$ & 73.08 & 16.318 & -0.97864 \\
\hline $\mathrm{U} 4(\mathrm{~N}=7)$ & 85.71 & 4.821 & +0.4340 \\
\hline $\mathrm{U} 5(\mathrm{~N}=1)$ & 84.62 & - & +0.3121 \\
\hline $\begin{array}{l}\text { Overall mean } \\
\text { score of the } \\
\text { participants }\end{array}$ & 81.83 & 8.941 & 0.0000 \\
\hline
\end{tabular}

Significance-: $\mathrm{ANOVA}=1.08, \mathrm{P}=0.36$

(TH1-1 ${ }^{\text {st }}$ Teaching hospital, TH2-2 ${ }^{\text {nd }}$ Teaching hospital, BH- Base hospital, U1-1 ${ }^{\text {st }}$ University,U2- $2^{\text {nd }}$ University ,U3-3 ${ }^{\text {rd }}$ University, U4-4 ${ }^{\text {th }}$ University, U5$5^{\text {th }}$ University)

Accordingly, the IMOs working in the Base Hospital has better knowledge than other two hospitals although there is no statistically significant association $(\mathrm{p}>0.05)$.Furthermore, The highest mean value for knowledge regarding legal importance of medical records was seen among graduates of $4^{\text {th }}$ University (85.71) and the least mean value for knowledge was seen among graduates of the $3^{\text {rd }}$ University (73.08). According to the analysis of the data, Mean value of the scores of all five universities lies within -1SD to $+1 \mathrm{SD}$. $(\mathrm{SD}=+/-8.941)$. There was no statistically significant difference in the mean scores of knowledge regarding legal importance within Universities.

The attitudes regarding the legal importance of medical records among IMOs was assessed based on the hospital they were working and their university of graduation. Total attitudes was divided into good and poor by the mean of the distribution and the number of participants(n) who had good and bad attitudes regarding legal importance of medical records were tabled against the hospitals. Mean values of scores for each university of graduation also tabled (Table2).

A statistically significant difference in the mean scores of attitudes of legal importance was found within Universities. However, within the post hoc test, a statistically significant difference was noted between the first and the second University only $(\mathrm{p}=0.0064)$.

Table 2. Attitudes regarding legal importance of medical records

\begin{tabular}{lrrr}
\hline Hospital & $\begin{array}{r}\text { Good } \\
\text { Attitudes } \\
\text { n(\%) }\end{array}$ & $\begin{array}{r}\text { Bad } \\
\text { Attitudes } \\
\mathbf{n}(\boldsymbol{\%})\end{array}$ & $\begin{array}{r}\text { Total } \\
\mathbf{N}=\mathbf{8 1}\end{array}$ \\
\hline $\mathrm{TH} 1$ & $42(52)$ & $07(08)$ & $49(60)$ \\
$\mathrm{TH} 2$ & $18(22)$ & $01(01)$ & $19(23)$ \\
$\mathrm{BH}$ & $07(09)$ & $06(07)$ & $13(16)$
\end{tabular}

Significance: $-\chi^{2}=9.807, \mathrm{DF}=2, \mathrm{P}=0.007$

\begin{tabular}{lrrr}
\hline $\begin{array}{l}\text { University } \\
\text { of } \\
\text { Graduation }\end{array}$ & $\begin{array}{r}\text { Mean } \\
\text { scores of } \\
\text { each } \\
\text { university }\end{array}$ & $\begin{array}{r}\text { Std. } \\
\text { Deviation }\end{array}$ & Z-score \\
& 76.04 & 5.103 & +0.3910 \\
$\mathrm{U} 1(\mathrm{~N}=24)$ & 62.88 & 18.876 & -0.4309 \\
$\mathrm{U} 2(\mathrm{~N}=33)$ & 62.50 & 17.678 & -0.4547 \\
$\mathrm{U} 3(\mathrm{~N}=2)$ & 82.14 & 12.199 & +0.7719 \\
$\mathrm{U} 4(\mathrm{~N}=7)$ & 75.00 & - & -0.3260 \\
$\mathrm{U} 5(\mathrm{~N}=1)$ & & & \\
& 69.78 & 16.012 & 0.0000 \\
$\begin{array}{l}\text { Overall } \\
\text { mean score }\end{array}$ & & & \\
of the \\
participants
\end{tabular}

Significance-: ANOVA $=5.8, \mathrm{P}=0.30014$

Majority of the participants of our study had good attitudes regarding legally important medical documents $(82 \%)$, and $94 \%$ of IMOs of the TH2 had good attitudes and there is statistically significant association $(p<0.05)$ indicating that attitudes of the IMOs depends on the hospitals they were based.

The highest mean value (82.14) for attitude has been achieved by $4^{\text {th }}$ University while the lowest mean value (62.50) for that has been achieved by $3^{\text {rd }}$ University according to our study. According to the analysis of the data, mean value of the scores of all five universities lies within $-1 \mathrm{SD}$ to $+1 \mathrm{SD}$. ( $\mathrm{SD}=+/-16.012)$ 
The practices regarding the legal importance of medical records among IMO was assessed based on the hospital they were working and their university of graduation. Total practices was divided into good and poor by the mean of the distribution and the number of participants(n) who had good and bad practices regarding legal importance of medical records were tabled against the hospitals. Mean values of scores for each university of graduation also tabled (Table3). There was no statistically significant difference in the mean scores of practices regarding legal importance within Universities.

Table 3. Practices regarding legal importance of medical records

\begin{tabular}{crrr}
\hline Hospital & $\begin{array}{r}\text { Good } \\
\text { practices } \\
\mathbf{n}(\%)\end{array}$ & $\begin{array}{r}\text { Bad } \\
\text { practices } \\
\mathbf{n}(\%)\end{array}$ & $\begin{array}{r}\text { Total } \\
\mathbf{N}=\mathbf{8 1}\end{array}$ \\
\hline TH1 & $31(38)$ & $18(22)$ & $49(60)$ \\
TH2 & $10(12)$ & $09(11)$ & $19(23)$ \\
BH & $11(14)$ & $02(02)$ & $13(16)$
\end{tabular}

Significance:- $\chi^{2}=3.482, \mathrm{DF}=2, \mathrm{P}=0.175$

\begin{tabular}{lrrr}
\hline $\begin{array}{l}\text { University } \\
\text { of } \\
\text { Graduation }\end{array}$ & $\begin{array}{r}\text { Mean } \\
\text { scores of } \\
\text { each } \\
\text { university }\end{array}$ & $\begin{array}{r}\text { Std. } \\
\text { Deviation }\end{array}$ & Z-score \\
\hline $\mathrm{U} 1(\mathrm{~N}=24)$ & 15.00 & 3.612 & +0.2938 \\
$\mathrm{U} 2(\mathrm{~N}=33)$ & 12.88 & 2.804 & -0.3051 \\
$\mathrm{U} 3(\mathrm{~N}=2)$ & 12.50 & 3.536 & -0.4124 \\
$\mathrm{U} 4(\mathrm{~N}=7)$ & 15.71 & 5.345 & +0.4943 \\
$\mathrm{U} 5(\mathrm{~N}=1)$ & 15.00 & - & -0.2938 \\
$\begin{array}{l}\text { Overall } \\
\text { mean score } \\
\text { of }\end{array}$ & 13.96 & 3.540 & 0.0000 \\
participants & & & \\
\hline
\end{tabular}

Significance-: $\mathrm{ANOVA}=2.5, \mathrm{P}=0.06$

Majority of the participants of our study had good practice regarding legally important medical documents (64\%), and $84 \%$ of IMOs of the Base Hospital has good practice although there is no statistically significant association $(\mathrm{p}>0.05)$.

Regarding the University of Graduation, the highest mean for the category "Practice regarding legally important medical documents" was seen among graduates of $4^{\text {th }}$ University $(15.71)$ and the least mean value for the same was seen among graduates of $3^{\text {rd }}$ University (12.5). According to the analysis, mean value of the scores of all five universities lies within $1 \mathrm{SD}$ to $+1 \mathrm{SD}$. $(\mathrm{SD}=+/-3.540)$
Overall performance among universities of graduation was assessed and tabled the mean scores of overall performances of each university (Table 4). There was a statistically significant difference in the mean scores of the overall performance regarding legal importance within the four Universities.

Table 4. Overall performance among universities of graduation $\mathbf{N}$ ?

\begin{tabular}{lrrr}
\hline $\begin{array}{l}\text { University } \\
\text { of } \\
\text { Graduation }\end{array}$ & $\begin{array}{r}\text { Mean } \\
\text { scores of } \\
\text { each } \\
\text { university }\end{array}$ & $\begin{array}{r}\text { Std. } \\
\text { Deviation }\end{array}$ & Z-score \\
\hline $\mathrm{U} 1(\mathrm{~N}=24)$ & 46.18 & 4.597 & +0.2215 \\
$\mathrm{U} 2(\mathrm{~N}=33)$ & 44.19 & 3.977 & -0.2283 \\
$\mathrm{U} 3(\mathrm{~N}=2)$ & 40.00 & 7.071 & -1.1754 \\
$\mathrm{U} 4(\mathrm{~N}=7)$ & 47.86 & 3.814 & +0.6013 \\
$\mathrm{U} 5(\mathrm{~N}=1)$ & 46.67 & - & +0.3323 \\
& & & \\
$\begin{array}{l}\text { Overall } \\
\text { mean score }\end{array}$ & 45.20 & 4.424 & 0.0000 \\
$\begin{array}{l}\text { of } \\
\text { participants }\end{array}$ & & & \\
\hline Signicis & & & \\
\hline
\end{tabular}

Significance-: $\mathrm{ANOVA}=3.0, \mathrm{P}=0.03$

The highest mean value (47.86) for the overall performance has been achieved by $4^{\text {th }}$ university while lowest mean value (40.00) for that has been achieved by $3^{\text {rd }}$ university according to our study. So, that indicates the IMOs who were graduated from $4^{\text {th }}$ university has better overall performance (knowledge, attitudes and practices) than the graduates from other faculties.

But as the highest mean value (47.86) is also below the 50.00 cut-off value for good performance as we considered: it indicates that overall performances of the graduates from the all selected universities are poor.

Number of participants who had given correct, incorrect answers and not answered were tabled assessing the knowledge about the situations which require an inquest in case of patient's death. (Table 5)

We inquired the knowledge of the IMOs about the situations where an inquest is required. According to the above results IMO $\mathrm{s}$ of our study population majority had very good knowledge $(>75 \%)$ for the most of the situations. Satisfactory knowledge was observed on deaths directly due to medication or/and surgical procedure. 
Table 5. Knowledge about the situations that require an inquest in case of death of a patient

\begin{tabular}{|c|c|c|c|}
\hline Situation & $\begin{array}{r}\text { Correct } \\
\text { n }(\%)\end{array}$ & $\begin{array}{r}\text { Incorrect } \\
\mathbf{n}(\%)\end{array}$ & $\begin{array}{l}\text { Don't } \\
\text { know } \\
\text { n }(\%)\end{array}$ \\
\hline $\begin{array}{l}\text { The cause of death is } \\
\text { known }\end{array}$ & $75(93)$ & $06(07)$ & $00(00)$ \\
\hline $\begin{array}{l}\text { Cause of death is known } \\
\text { but is an unnatural death }\end{array}$ & $74(91)$ & $06(08)$ & $01(01)$ \\
\hline Suspicious death & $72(89)$ & $03(04)$ & $06(07)$ \\
\hline $\begin{array}{l}\text { Deaths directly due to } \\
\text { medication or/and } \\
\text { surgical procedure }\end{array}$ & $59(79)$ & $12(15)$ & $10(12)$ \\
\hline $\begin{array}{l}\text { Deaths in custody, } \\
\text { prisons, mental and } \\
\text { leprosy hospitals }\end{array}$ & $78(96)$ & $03(04)$ & $00(00$ \\
\hline $\begin{array}{l}\text { Alleged medical } \\
\text { negligence }\end{array}$ & $75(93)$ & $05(06)$ & $01(01)$ \\
\hline $\begin{array}{l}\text { Deaths due to animal } \\
\text { bites }\end{array}$ & $42(52)$ & $19(23)$ & $20(25)$ \\
\hline $\begin{array}{l}\text { A natural death when } \\
\text { the cause of death is } \\
\text { known but occurs } \\
\text { within } 24 \mathrm{hrs} \text { of } \\
\text { admission }\end{array}$ & $19(23)$ & $51(63)$ & $11(01)$ \\
\hline
\end{tabular}

Regarding the situation about the deaths due to animal bites although majority had given the correct answer; only $52 \%$ had known that an inquest was needed. Majority had given incorrect answers for the situation of a natural death when the cause of death is known but occurs within $24 \mathrm{hrs}$ of admission.

\section{Discussion}

The legal aspects of health care are being clearly highlighted with the rise of complaints made regarding medical negligence and also in the on-going process of elevating Sri Lankan health care setup to international standards. Most of the doctors working in Sri Lanka are produced by the Sri Lankan universities. They receive their knowledge on legal aspects of health care almost exclusively as a part of their undergraduate training under the Forensic Medicine stream and will not receive any further knowledge on the matter unless they start following forensic medicine stream. Medical records play a huge role when considering the legal aspects of health care as they can be produced and be challenged in a court of law. By understanding the level of knowledge, attitude and current practice, it would be helpful to educate the future doctors and to renew the knowledge of all the practicing doctors in an optimum way. The medico-legal expertise journal article as discussed by James D. Sullivan highlights the importance of including medico legal aspects in the field of medicine in the medical curriculum. ${ }^{[5]}$

Bed head ticket (BHT) is one of the most important, contemporaneous medical records having best evidentiary value in a court. Hence, it must be maintained and updated regularly and preserved carefully after the patient is discharged. Proper knowledge, attitude and practice regarding this very important medical record is therefore vital and our research by means of a self-administered questionnaire assessed this by 16 closed-ended questions.

The court accepts any individual in any field who has a practical knowledge and experience to give evidence in the court as an "expert" in that particular field. In the medical profession; a medical officer with MBBS or its equivalent recognized by the Sri Lanka Medical council; is considered as an expert according to the article "Medical expert witness persistent challenge explored" by UC Perera. ${ }^{[6]}$

Therefore, majority of the study population was educated that an ordinary medical officer is an expert witness. Here the legal importance of the medical documents come in to play, as the evidence has to be supported with properly documented medical records.

Informed consent refers to the process whereby patient and the care practitioner involve in a dialogue about medical treatment, its nature, consequences, benefits, risks, complications etc. It indirectly ensures patient safety by opening a conversation between the patient and medical personnel so that the patient can ask questions, know what to expect during and after procedures and clarify any doubts, improving physician-patient communication. Hence, written informed consent is mandatory and very important in a Sri Lankan hospital setup. Additionally, educating the patient has been associated with preventing medical errors. Reviews and focus groups have shown to prove this as well. ${ }^{[7]}$ To obtain a valid consent, the factors to be taken into account will include but not limit to patient's age and maturity, physical and mental state, intellectual capacity, standard of education and reason for the procedure, operation or the treatment.

The IMOs had mentioned the right instances in which written informed consent is absolutely essential. Multiple studies have shown that most patients are unable to recall or understand most of the information that is presented to them in the informed consent process. 
Death of a patient is a situation that every IMOs experience in their day to day work. In the "medical and death certificates" Sri Lanka Medical council (May 2004); "Under Section 31 of the Births \& Deaths Registration Act (Cap 129) it is stated that; It is the medico legal duty of the attending doctor to issue the medical certificate of cause of death if known, when a patient he is treating dies due of a natural cause. ${ }^{[8]}$ This highlights that the IMOs is entitled to certify a death occurring in the ward. Certification of death includes a standard procedure including identification of absence of pupillary reflexes, respiration, circulation etc. of the deceased, recording on the BHT if the death is confirmed, notifying the relatives of the deceased, informing the seniors about the death and issuing of the medical certificate of cause of death. In the journal article "Inquests and doctors" by L. Fernando says "When an inquest is necessary, it is the responsibility of the treating doctor to inform the police about this need. Most junior doctors do not have adequate knowledge as to whom they should ask for an inquest. ${ }^{[9]}$ "An inquest is conducted to find out the cause when unknown or is suspected to not be due to natural causes. In our study we inquired the knowledge of the IMOs about the situations where an inquest is required and following results were gained. (Table 5)

First seven situations in the table 5 needs an inquest while the last situation does not require and inquest. ${ }^{[9]}$ The cause of death may be ascertained and if it is determined to be a natural one, the body can be released without an inquest. An inquest must be requested on all deaths certified at the Out Patient Department (OPD)". Among the IMOs of our study population, majority had very good knowledge $(>75 \%)$ on most situations, except for the following situations: Deaths directly due to medication or/and surgical procedure, which showed satisfactory knowledge. Regarding the practice in Sri Lanka, majority had given incorrect answers for the situation; A natural death when the cause of death is known but occurs within $24 \mathrm{hrs}$ of admission. It can be deduced that IMO's need better knowledge on inquests.

With regards to the University of Graduation of the IMOs who were included in our research study; $4^{\text {th }}$ University had scored the highest mean of 47.68 for the overall performance while $3^{\text {rd }}$ University had scored the least mean value of 40.00 .But as the highest mean value (47.68) is also below 50.00 which was our cutoff value for good performance, it indicates that overall performances of the graduates from all the selected universities are poor. It emphasizes the necessity of the improvement of the knowledge on the legal importance of medical documents; of the graduates who pass out from the universities to upgrade the performance when they become a medical officer.

Acknowledgment of legal importance of medical reports was an important objective of our study. For the continuity of care of patients, it is vital to keep proper medical records and to handle them with proper knowledge, attitude and practice. It is also vital for health professionals for defending a complaint / clinical negligence claim. ${ }^{[1]}$ In general, if records are adequate enough for continuity of care, it will be qualified for legal use. Purpose of this segment of assessment was to see if our medical officers believed that he/she had acquired adequate knowledge and information on legal importance of medical record keeping as an undergraduate and if they were satisfied about the level of awareness and knowledge regarding the matter as an intern during orientation period to which most of them had responded to positively.

\section{Conclusions}

The results obtained regarding knowledge showed that the highest mean value for knowledge was seen among graduates of $4^{\text {th }}$ University (85.71) and the least mean value for knowledge was among the graduates of $3^{\text {rd }}$ University (73.08). The highest mean value for attitude according to our data was achieved by graduates of $4^{\text {th }}$ University (82.14) and the least mean value for attitude by graduates of $3^{\text {rd }}$ University (62.50).

The highest mean value for Practice was seen among graduates of $4^{\text {th }}$ University (15.71) and the least by the graduates of $3^{\text {rd }}$ university (12.5). Thus the highest mean value for overall performance was achieved by the graduates of $4^{\text {th }}$ University (47.86) and the least mean value for overall performance was achieved by

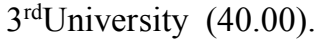

Hence we can draw the conclusion that in terms of knowledge, attitude and current practices in maintaining legally important medical records all IMOs who graduated from all Universities were similar.

Thus we can finally conclude that based on the findings of our research the graduates of all Universities and the IMO's working at 1st Teaching hospital may have better overall performance in terms of knowledge, attitude and current practices in maintaining legally important medical records in comparison with the others. However, this needs to be researched further with other confounding variables.

\section{Conflict of interests}

Financial and non-financial: None 


\section{Declaration}

The authors declare that, this research paper was not published or not under consideration in part or as a whole in any other journal or a proceeding.

\section{References}

1. Thomas J. Medical records and issues in negligence. Indian J Urol. 2009 Jul;25(3):384-8. https://doi.org/10.4103/ 0970-1591.56208. [cited 2019 Jun 3]

2. Ruwanpura R. Litigation against medical practitioners: facts and myths. Gall Med J. 2009 Oct 8;14(1):56-8. Doi. http://doi.org/ 10.4038/ gmj.v14i1.1176. [cited 2019 Jun 3]

3. Rupasinghe P. Medical Negligence and Doctor`s Liability; A Critical Review in Present Legal Regime in Sri Lanka. 2015; Proceedings of 8th International Research Conference, KDU, Nov.2015:260-65. [cited 2019 Jun 3]

4. Goonasekera CD. Medical indemnity in state hospitals: Whose baby is it?. Sri Lanka Journal of Child Health. 2011 Mar 14;40(1):35-7.DOI: 10.4038/sljch.v39i4.2875

5. Sullivan JD. The medico-legal expertise: solid medicine, sufficient legal and a measure of common sense. Mcgill J Med . 2006 Jul;9(2):14751. [cited 2019 Jun 3]

6. Perera UC. Medical expert witness: persistent challenge unexplored. Galle Medical Journal. 2007 Sep 15;12(1):52-5. Doi: 10.4038/gmj.v12i1.1089

7. Michels D, Cahill M. Informed consent and chemotherapy. Journal of oncology practice. 2005 Sep;1(3):99.doi:10.1200/jop.2005.1.3.99

8. Sri Lanka Medical Council Medical and Death Certificates. 2004. Available from: http:/www.srilankamedical council. org/ download /download/4/9cb 039ff81 a7784ff809e19f7937d754.pdf. [cited 2019 Jun 3]

9. Fernando L. Inquests and doctors. Galle Med J. 2009 Sep 28;11(1) : 37-8. Doi: 10.4038/ gmj.v11i1.1120. [cited 2019 Jun 3] 